V. Rosickÿ

By F. Slavik. Pp. 24. (Prague: Czech Academy of Science and Arts, 1946.) 12 crowns.

DROF. VOJTECH ROSICKY் was a distinguished Czech mineralogist whose scientific work was cut short by his execution at Mauthausen concentration camp in February 1942, in his sixty-second year. His father, who died in 1919, had been a naturalist and writer on scientific subjects, and young Rosický grew up in an atmosphere of excursions to forest and mountains in search of specimens. He began as science master at a Prague Gymnasium, for which he wrote a "Chemie a Mineralogie". Later he went to Munich as Groth's assistant; eventually he returned to Prague and, in 1920 , became professor of minerálogy at the new University of Brno. His publicationsmostly in Czech although some appeared in the Zeitschrift für Krystallographie and in French journals - dealt with crystallographic methods, the physical properties and measurements of crystals and the relation between physical properties and water content. $\mathrm{He}$ described, often in great detail, a variety of minerals from Europe, South Africa and South America, including a joint work with V. M. Goldschmidt on a topaz from Minas Geraes. Rosický also made some petrographical studies and wrote several text-books, including a lengthy "Krystalografie", one volume of which appeared in 1929 (with more than five hundred illustrations). The second half he left in manuscript, which is now being prepared for publication by Dr. J. Sekanin, with whom he was conducting $\mathrm{X}$-ray crystallographic researches until the University was closed in 1939.

Prof. Slavik, himself a mineralogist well known in Britain, has written this short biography in appreciation of his countryman's contributions to mineralogy. J. G. F. D.

\section{L'Organisme en lutte contre les microbes}

Par André Boivin et Albert Delaunay. (L'Avenir de la science, 24). Pp. $425+15$ plates. (Paris: Libr. Gallimard, 1947.) 320 francs.

7 HIS latest addition to Gallimard's popular science series is of the same high standard as its predecessors, some of which have already been reviewed in Nature. Without diminution of scientific value the subject has been reduced to terms which can be understood by non-medical readers, but the book would be useful and easy reading for medical students preparing for examination.

The first part describes bacteria and viruses and the nature and evolution of infectious diseases. The second part describes the body's defences against invading organisms; the role of the phagocytes, antigens and antibodies. Part three deals with prevention and treatment of infectious diseases. Recent advances in chemotherapy and antibiotics are included. There is a detailed list of contents, but, unfortunately, no proper index.

\section{The Annual Register}

A Review of Public Events at Home and Abroad for the Year 1946. Edited by H. T. Montague Bell. Pp. xii + 504. (London, New York and Toronto : Longmans, Green and Co., Ltd., 1947.) 42s. net.

THIS valuable volume makes its one hundred and eighty-eighth appearance as a full and objective record of the year's events. It is under new editorship, Dr. Epstein having died during the past year, but retains its well-established plan and scope.
British history is told in four sections, followed by the history of the Commonwealth and Empire, with the troubled story of India and Burma. Then an equal share is devoted to foreign history, including the United Nations Organisation. Here the four Great Powers have the major part, but naturally the States of the troubled eastern side of Europe receive considerable attention. The latter part of the book is devoted to the usual chronicle of the year, obituaries and surveys of literature, art, science and finance. The public documents printed in full are the Anglo-Siamese agreement, the Yalta agreement and the White Paper on India.

\section{Outlines of the Geography, Life and Customs of Newfoundland-Labrador (the Eastern Part of} the Labrador Peninsula)

Based upon Observations made during the FinlandLabrador Expedition in 1937, and the Tanner Labrador Expedition in 1939, and upon Information available in the Literature and Cartography. By Prof. V. Tanner. Vol. 1. Pp. ii +436 . Vol. 2. Pp. ii + 437-909. (Cambridge: At the University Press, 1947.) 2 vols., 50s. net.

T ABRADOR has a considerable literature of its own, as the full bibliography in this volume shows, but it is mainly concerned with the coastal regions which constituted that part of Labrador under the rule of Newfoundland. In 1927 the Privy Council brought within Newfoundland-Labrador the Atlantic drainage, leaving the remainder to Canada. Thus an area of about 100,000 square miles is a dependency of the former dominion of Newfoundland. The two large and beautifully illustrated volumes of this work, originally printed in Finland in Acta Geographica, do not claim to present a completely co-ordinated geography of Labrador. They contain rather the raw materials of such a work, from which much can be deduced. But the work is admittedly incomplete, partly because of the vastness of the area and partly because the second expedition of Prof. Tanner in 1939 was interrupted by the outbreak of war. It is, however, of interest to note that Prof. Tanner, versed in the conditions of Finland, sees no reason why much of Labrador should not eventually be colonized, even if it cannot become a self-supporting agricultural country.

\section{Know an Island}

By R. M. Lockley. (Harrap's Country-Lovers Library.) Pp. 243. (London : George G. Harrap and Co., Ltd., 1947.) $8 s .6 d$. net.

TLANDS where the sea-birds come to breed have a peculiar fascination, an appeal felt early and with great force by Mr. R. M. Lockley. He was not happy until he had acquired one, and even then he was not satisfied. Skokholm, that sanctuary of Manx shearwaters, storm petrels, puffins, etc., off the Pembrokeshire coast of Wales, only whetted his appetite for islands. In his book "I Know an Island", first published in 1938 and now reprinted, he tells of his own island of Skokholm, the neighbouring islands of Skomer, Grassholm and Ramsey and their inhabitants, both winged and furred, before going on to islands farther afield. The Blaskets off the Irish coast, Heligoland, Fair Isle, the Faeroes and the Westermann Islands are among those visited and interestingly described, with special reference to ornithological matters. For example, Mr. Lockley searched far for Leach's fork-tailed petrel, to find it at last on Sudurey in the Westmann Islands. F. PrTT 